\title{
ANALISIS PENGENDALIAN KUALITAS PRODUKSI AIR MINUM DALAM KEMASAN STUDI KASUS PADA CV JAYA ABADI SEJAHTERA
}

\author{
Dwyki Retno Anggrayni ${ }^{*}$, Jaryono ${ }^{1}$, Suci Indriati ${ }^{1}$, Ary Yunanto ${ }^{1}$ \\ ${ }^{1} J u r u s a n$ Manajemen, Fakultas Ekonomi dan Bisnis, Universitas Jenderal Soedirman, Indonesia \\ *Email corresponding author: dwykiretnoa@gmail.com
}

\begin{abstract}
ABSTRAK
Penelitian ini merupakan penelitian observasi pada kualitas produksi air minum dalam kemasan $220 \mathrm{ml}$ pada CV Jaya Abadi Sejahtera yang berada di desa Sumbang, Purwokerto. Penelitian ini mengambil judul: "Analisis Pengendalian Kualitas Produksi Air Minum Dalam Kemasan (Studi Kasus Pada CV Jaya Abadi Sejahtera)". Tujuan penelitian ini adalah untuk mengetahui tingkat pengendalian kualitas produk serta proses produksi pada CV Jaya Abadi Sejahtera. Untuk mengetahui tingkat pengendalian kualitas produk serta proses produksi tersebut bisa dilihat dari data-data yang beracuan pada standar air minum yang sudah dibakukan pada SNI 3553:2015, dengan ketentuan standar pada tingkat kekeruhan, pH, serta zat terlarut. Populasi dalam penelitian ini adalah seluruh produk air minum dalam kemasan yang di produksi oleh CV Jaya Abadi Sejahtera. Sampel dalam penelitian ini merupakan jenis produksi produk air minum dalam kemasan yang jumlah penjualannya paling laku dipasaran. Jumlah sampel yang diambil 70 buah air minum dalam kemasan, dengan penelitian yang dilakukan selama 14 hari, dengan setiap harinya dilakukan penelitian pada 5 sampel. Metode purposive sampling digunakan dalam penentuan jenis sampel. Berdasarkan hasil penelitian dan analisis menggunakan metode statistical quality control menunjukan bahwa: (1) Nilai Grafik pada Control Chart Kekeruhan, pH, serta Zat yang Terlarut beberapa kali mengalami nilai stagnan, yang artinya terdapat penyebab khusus yang mempengaruhi proses produksi tersebut, sehingga proses produksi tidak stabil, (2) Nilai Cp dan Cpk pada setiap standar produk memiliki nilai lebih dari 1, yang artinya proses produksi berjalan dengan baik, (3) Penyebab utama dari defect pada produk air kemasan tersebut bukanlah pada kualitas bahan bakunya, melainkan karena produk yang terjatuh saat berada diruang penyimpanan sebanyak 523 buah $(65.79 \%)$, serta produk kurang isi sebanyak 272 buah (34.21\%). Implikasi dari kesimpulan diatas yaitu melakukan perbaikan atas ketidakstabilan proses produksi, melakukan pelatihan kepada pegawai yang bertugas untuk mengoperasikan mesin pengisian kemasan, serta memperbaiki ruang penyimpanan agar produk tidak mudah terjatuh.
\end{abstract}

Kata Kunci: pengendalian kualitas, produk cacat, statistical quality control

\begin{abstract}
This research is an observational study on the quality of $220 \mathrm{ml}$ bottled drinking water production in CV Jaya Abadi Sejahtera located in the village of Sumbang, Purwokerto. This research takes the title: "Analysis of Quality Control of Bottled Drinking Water Production (Case Study in CV Jaya Abadi Sejahtera)". The purpose of this study was to determine the level of product quality control and production processes at CV Jaya Abadi Sejahtera. To find out the level of product quality control and the production process can be seen from the data referenced to drinking water standards that have been standardized in SNI 3553: 2015, with standard provisions on turbidity, $\mathrm{pH}$, and solute levels. The population in this study are all bottled drinking water products produced by CV Jaya Abadi Sejahtera. The sample in this study is the type of production of bottled drinking water products whose sales are most salable in the market. The number of samples taken was 70 bottled drinking water, with research carried out for 14 days, with daily research conducted on 5 samples. The purposive sampling method is used in determining the type of sample. Based on the results of research and analysis using statistical quality control methods show that: (1) Graph Value on Turbidity, $\mathrm{pH}$, and Dissolved Substance Control Charts have stagnated several times, which means that there are special causes that affect the production process, so the production process does not stable, (2) the value of Cp and Cpk on each product standard has a value of more than 1, which means the production process is going well, (3) The main cause of the defect in the bottled
\end{abstract}


water product is not the quality of the raw material, but because the product has fallen while in the storage room there were 523 pieces (65.79\%), as well as 272 pieces of defective products (34.21\%). The implication of the conclusion above is to make improvements to the instability of the production process, conduct training for employees who are tasked with operating the packaging filling machine, and improve storage space so that the product does not fall easily.

Keywords : quality control, product defects, statistical quality control.

\section{PENDAHULUAN}

Persaingan yang terjadi dalam dunia bisnis merupakan suatu hal yang tidak dapat dihindari, baik dalam pasar lokal maupun pasar internasional. Persaingan yang terjadi dalam masa kini lebih kepada persaingan tingkat kualitas suatu produk, ini terjadi untuk terwujudnya kepuasan konsumen dan untuk dapat bersaing dengan perusahaan lain didalam industri yang sejenis. Prioritas peningkatan kualitas suatu produk harus lebih diutamakan bagi setiap perusahaan karena ini suatu cara untuk dapat memenangkan persaingan bisnis. Maka dari itu setiap perusahaan harus dapat mempertahankan atau bahkan meningkatkan kualitas suatu barang atau jasa yang mereka produksi agar konsumen dapat memenuhi kebutuhannya secara memuaskan.

Tabel 1. Spesifikasi Kualitas Air Minum Dalam Kemasan 220ml

\begin{tabular}{ccc}
\hline \multirow{2}{*}{ Spesifikasi Kualitas } & \multicolumn{2}{c}{ Kualifikasi } \\
\cline { 2 - 3 } Kekeruhan & Min & Max \\
$\mathrm{pH}$ & $0,00 \mathrm{NTU}$ & $1,5 \mathrm{NTU}$ \\
Zat yang terlarut & 6,0 & 8,5 \\
\hline
\end{tabular}

Sumber : SNI 3553:2015

Salah satu persyaratan yang ditetapkan oleh pemerintah dalam hal ini SNI adalah kualitas dari air minum. Dalam penelitian ini yang ingin saya teliti mengenai kualitas dari produk air minum dalam kemasan $220 \mathrm{ml}$ produksi CV Jaya Abadi Sejahtera yang beracuan pada SNI 3553:2015 serta kapabilitas proses yang terjadi pada saat proses produksi air minum dalam kemasan tersebut. Hal yang biasa dijadikan patokan kualitas pada produk air minum dalam kemasan diantaranya kekeruhan, $\mathrm{pH}$, serta zat yang terlarut yang besarannya sudah tercantum dalam tabel 1.

Berdasarkan data penelitian awal yang ada pada tabel 2 pada bagian produksi diperoleh data produksi dan defect pada produk air minum dalam kemasan 220 ml pada bulan Juli 2019 dengan jumlah produksi 5442 pcs dan produk defect 779 pcs. Serta berdasarkan wawancara awal dengan manager operasional sub bagian pengendalian kualitas pada CV Jaya Abadi Sejahtera adanya jumlah defect berarti menunjukkan adanya penyimpangan hasil produksi dengan standar kualitas yang telah ditentukan diantaranya kekeruhan, $\mathrm{pH}$, serta zat yang terlarut, yang terdapat pada tabel 1 . Untuk penyebab dari penyimpangan hasil produksi biasanya diakibatkan oleh bahan baku yang tidak sesuai standar atau dari kesalahan manusia.

Tabel 2. Data Produksi dan Defect Produk Air Minum Kemasan 220 ml Bulan Juli 2019 


\begin{tabular}{rrrr}
\hline No. & \multicolumn{1}{c}{ Tanggal } & Jumlah Produksi (pcs) & Jumlah Defect (pcs) \\
\hline $\mathbf{1}$ & 3-Jul-19 & 192 & 24 \\
$\mathbf{2}$ & 4-Jul-19 & 690 & 54 \\
$\mathbf{3}$ & 5-Jul-19 & 336 & 57 \\
$\mathbf{4}$ & 6-Jul-19 & 336 & 50 \\
$\mathbf{5}$ & 8-Jul-19 & 336 & 108 \\
$\mathbf{6}$ & 9-Jul-19 & 288 & 95 \\
$\mathbf{7}$ & 10-Jul-19 & 448 & 30 \\
$\mathbf{8}$ & 11-Jul-19 & 288 & 84 \\
$\mathbf{9}$ & 12-Jul-19 & 288 & 72 \\
$\mathbf{1 0}$ & 13-Jul-19 & 288 & 72 \\
$\mathbf{1 1}$ & 18-Jul-19 & 528 & 90 \\
$\mathbf{1 2}$ & 29-Jul-19 & 192 & 28 \\
$\mathbf{1 3}$ & 30-Jul-19 & 992 & 10 \\
$\mathbf{1 4}$ & 31-Jul-19 & 240 & 5 \\
& Total & 5442 & 779 \\
\hline
\end{tabular}

Sumber: CV Jaya Abadi Sejahter

Untuk mengidentifikasi dampak produk rusak pada produk air minum dalam kemasan di CV Jaya Abadi Sejahtera dapat digunakan metode Statistical Quality Control. Statistical Quality Control adalah suatu system yang dikembangkan untuk menjaga standar yang seragam dari kualitas hasil produksi (Sofjan Assauri : 2004). Dalam SQC terdapat tujuh alat bantu yang dapat digunakan, diantaranya; (1) Diagram Pareto, (2) Diagram Sebab Akibat, (3) Diagram Scatter, (4) Lembar Pengecekan (check sheet), (5) Control Chart (variabel dan atribut), (6) Histogram, (7) Flowchart. Dalam penelitian ini peneliti akan menggunakan control chart dengan jenis variabel. Penggunaan control chart jenis variabel dikarenakan dalam penelitian ini objek yang diteliti memiliki dimensi yang terus menerus, serta memiliki jumlah kemungkinan yang tak terbatas. Pengukuran yang dilakukan dalam control chart variabel diantaranya menggunakan $x$-chart dan $R$-chart.

Berdasarkan beberapa penelitian sebelumnya, ternyata penelitian mengenai kualitas suatu produk dengan menggunakan Statistical Quality Control (SQC) dirasa cukup efektif dalam menemukan sumber-sumber permasalahan tentang pengendalian kualitas dari suatu produk. Seperti penelitian sebelumnya yang dilakukan oleh Debrina Puspita Andriani (2017), yang meneliti tentang kualitas kadar air pada produk kerupuk udang berbasis SNI dengan hasil terdapat 5 data yang berada diluar batas standar presentase kandungan air kerupuk udang sesuai dengan Standar Nasional Indonesia (SNI) yaitu sebesar 12 persen tidak terpenuhi. Faktor utama terjadinya penyimpangan di antaranya faktor material terdapat permasalahan pallet yang terlalu tebal serta dari faktor mesin terdapat permasalahan suhu mesin dryer yang tidak stabil.

Selanjutnya penelitian yang dilakukan oleh Aldik Hilmawan (2016), yang meneliti tentang kualitas genteng di UKM Super Soka Jepara, dengan hasil 81,05 persen retak pada proses pengeringan pertama, 32,94 persen retak pada proses pembersihan ke-2, serta pecah 63,16 persen. Dari hasil penghitungan data menggunakan $\bar{X}$ dan $\bar{R}$ pada masing-masing proses, terdapat beberapa data yang berada diluar batas kendali yaitu pada proses pencetakan dan pengeringan ke-2.

Ahmad Yani, ST \& Ir. Timbul H. Simanjuntak, MT (2014) meneliti tentang "Analisa Pengendalian Kualitas Flat Flexibel Cable (FFC) dengan Menggunakkan Peta X dan R di PT 
Totoku Indonesia". Alat analisis yang digunakan di antaranya Check Sheet, Peta Kendali X, Peta Kendali R, Diagram Sebab Akibat. Berdasarkan penelitian tersebut dapat disimpulkan bahwa terdapat 3 proses proses yang berpotensi menciptakan kecacatan paling tinggi yaitu pada proses cutting, buka/tutup dan geser stopper, serta langkah sensor cutting.

Selain mengetahui dampak produk rusak pada produk air minum dalam kemasan di CV Jaya Abadi Sejahtera, peneliti juga ingin mengetahui kapabilitas pada proses produksi air minum dalam kemasan tersebut. Maka untuk mengetahui hal tersebut peneliti menggunakkan metode Analisis Kapabilitas Proses. Dalam analisis kapabilitas proses tersebut terdapat dua rumus yang digunakan diantaranya Rasio Kabapilitas Proses serta Indeks Kapabilitas Proses. Tujuan dari penelitian ini adalah untuk menganalisis pengendalian kualitas produk serta prosess produksi pada CV Jaya Abadi Sejahtera. Penelitian ini meneliti apakah pengendalian kualitas pada produk air mineral kemasan pada CV Jaya Abadi Sejahtera berada dalam batas kendali atau tidak. Ini dilakukan dengan cara melakukan observasi pada tiga kriteria yang sudah ditentukan oleh SNI 3553:2015, diantaranya kekeruhan, $\mathrm{pH}$, serta zat yang terlarut.

Berdasarkan penyimpangan hasil produksi yang sudah dipaparkan diatas, peneliti tertarik untuk melakukan penelitian dengan judul "Analisis Kapabilitas Proses Produksi Air Minum Dalam Kemasan Dengan Pendekatan Bagan Kendali (Studi Kasus Pada CV Jaya Abadi Sejahtera)"

\section{TINJAUAN PUSTAKA DAN PERUMUSAN HIPOTESIS \\ Kualitas}

Menurut Tjiptono dan Sunyoto (2012) kualitas merupakan: "Suatu ukuran untuk menilai bahwa suatu barang atau jasa telah mempunyai nilai guna yang dikehendaki atau dengan kata lain suatu barang atau jasa dianggap telah memiliki kualitas apabila berfungsi atau mempunyai nilai guna seperti yang diinginkan.

Kualitas merupakan suatu ukuran untuk menilai bahwa suatu barang atau jasa telah mempunyai nilai guna yang dikehendaki atau dengan kata lain suatu barang atau jasa dianggap telah memiliki kualitas apabila berfungsi atau mempunyai nilai guna seperti yang diinginkan. Pengawasan mutu merupakan usaha untuk mempertahankan mutu/kualitas dari barang yang dihasilkan, agar sesuai dengan spesifikasi produk yang telah ditetapkan berdasarkan kebijaksanaan pimpinan perusahaan

\section{Pengendalian Kualitas}

Pengendalian dan pengawasan adalah kegiatan yang dilakukan untuk menjamin agar kegiatan produksi dan operasi yang dilaksanakan sesuai dengan apa yang direncanakan dan apabila terjadi penyimpangan, maka penyimpangan tersebut dapat dikoreksi sehingga apa yang diharapkan dapat tercapai (Sofjan Assauri: 2008).

\section{Statistical Quality Control}

Statistical Quality Control merupakan metoda statistik untuk mengumpulkan dan menganalisis data hasil pemeriksaan terhadap sampel dalam kegiatan pengawasan kualitas produk. SQC dilakukan dari pengambilan sampel (sampling) dari "populasi" dan menarik kesimpulan berdasarkan karakteristik sampel tersebut secara statistic atau statistical inference. Pengambilan sampel ini juga memiliki risiko, karena tidak seluruh sampel mempunyai karakteristik yang sama secara tepat sebagai keseluruhan.

Dalam manajemen Kualitas ada beberapa teknik perbaikan yang biasanya digunakan dalam organisasi. Teknik-teknik dasar yang biasa digunakan antara lain Diagram Pareto, Histogram, Lembar Pengecekan (checksheet), Diagram Sebab Akibat, Diagram Alur, Diagram Penyebaran (scatter diagram), Peta Pengendali dan Analisis Kapabilitas Poses. 
Analisis Kapabilitas Proses mendefinisikan kemampuan proses memenuhi spesifikasi atau mengukur kinerja proses. Tujuan dilakukannya AKP adalah memprediksi variabilitas proses yang ada, serta menguji teori mengenai penyebab kesalahan selama program perbaikan kualitas. Alasan utama dalam mengkuantifikasikan kemampuan proses untuk dapat berpegang pada spesifikasi produk (Arini: 2004). Ukuran dari kapabilitas proses disebut indeks kapabilitas yaitu Cp dan Cpk. Indeks kapabilitas suatu proses adalah perbandingan variasi proses terhadap spesifikasi yang telah ditentukan. Nilai indeks kapabilitas minimum untuk distribusi normal adalah satu.

Dalam penelitian ini ada beberapa penelitian yang dijadikan acuan oleh penulis diantaranya adalah: (1) Debrina Puspita Andriani et al (2017) meneliti tentang "Pengendalian Kualitas Kadar Air Produk Kerupuk Udang Berbasis SNI menggunakan Statistical Quality Control". Alat analisis yang digunakan di antaranya Check Sheet, Peta kendali rata-rata $(\bar{X})$, Peta Kendali Jarak $(\bar{R})$, Indeks Kapabilitas Proses, Diagram Tulang Ikan. Dari penelitian tersebut didapat kesimpulan bahwa persentase kandungan air pada kerupuk udang terdapat 5 data yang berada diluar batas kendali X dan 1 data berada pada peta kendali R. (2) Aldik Hilmawan (2016), yang meneliti tentang "Pengendalian Kualitas Statistical Process Control Produk Genteng di UKM Super Soka Jepara”. Alat analisis yang di gunakan di antaranya Check Sheet, Diagram Sebab Akibat, Histogram, Diagram Pareto, Diagram Scatter, X chart, R chart. Dengan hasil penelitian $81,05 \%$ retak pada proses pengeringan pertama, 32,94\% retak pada proses pembersihan ke-2, serta pecah 63,16\%. Dari hasil penghitungan data menggunakan $\bar{X}$ dan $\bar{R}$ pada masing-masing proses, terdapat beberapa data yang berada diluar batas kendali yaitu pada proses pencetakan dan pengeringan ke-2. (3) Ahmad Yani, ST \& Ir. Timbul H. Simanjuntak, MT (2014) meneliti tentang "Analisa Pengendalian Kualitas Flat Flexibel Cable (FFC) dengan Menggunakkan Peta X dan R di PT Totoku Indonesia". Alat analisis yang digunakan di antaranya Check Sheet, Peta Kendali X, Peta Kendali R, Diagram Sebab Akibat. Dari penelitian tersebut dapat disimpulkan bahwa terdapat 3 proses proses yang berpotensi menciptakan kecacatan paling tinggi yaitu pada proses cutting, buka/tutup dan geser stopper, serta langkah sensor cutting.

\section{METODE PENELITIAN DAN TEKNIK ANALISIS DATA Jenis Penelitian}

Penelitian ini merupakan penelitian observasi mengenai pengendalian kualitas produk air minum dalam kemasan, dimana peneliti melakukan pengamatan pada data produk gagal.

\section{Populasi dan Sampel Penelitian}

Populasi dari penelitian ini adalah keseluruhan obyek yang ingin diteliti. Dalam hal ini adalah keseluruhan produk air minum dalam kemasan yang diproduksi oleh CV Jaya Abadi Sejahtera. Sampel adalah sebagian atau wakil populasi yang diteliti. Dalam penelitian ini akan digunakan metode purposive sampling dimana tidak berdasarkan random, daerah maupun strata, melainkan berdasarkan pertimbangan yang berfokus pada tujuan tertentu (Arikunto : 2006). Adapun beberapa pertimbangan yang telah ditentukan sebagai berikut: Jenis produk air minum dalam kemasan yang paling laku dipasaran

\section{Jenis dan Sumber Data}

Data yang digunakan dalam penelitian ini merupakan data sekunder. Sumber data yang digunakan dalam penelitian ini diambil dari dokumen atau data yang didapat dari hasil observasi pada quality control CV Jaya Abadi Sejahtera. 


\section{Teknik Pengumpulan Data}

Teknik pengumpulan data dalam penelitian ini menggukanakan studi pustaka dan dokumentasi. Studi Pustaka dilakukan dengan mempelajari buku, jurnal, artikel, dan hasil penelitian yang berhubungan dengan masalah yang akan diteliti, sedangkan Pengumpulan data dengan teknik observasi melakukan pencatatan pada pengamatan langsung pada proses quality control CV Jaya Abadi Sejahtera sejak 18 September 2019 - 3 Oktober 2019.

\section{Teknik Analisis Data}

Pada penelitian ini dilakukan beberapa langkah dalam melakukan teknik analisis data, diantaranya:

Check Sheet

Histogram

Grafik Kendali

Dalam grafik kendali ini terdapat beberapa langkah untuk memporoleh hasilnya, diantaranya:

Tentukan ukuran sampel

Hitung Nilai X dan R dari setiap sampel

$$
\begin{aligned}
& \bar{X}=\frac{\sum X_{i}}{n_{i}} \\
& \text { Keterangan: } \\
& \bar{X} \quad=\text { rata-rata } X \\
& \sum X_{i} \quad=\text { jumlah } X \\
& n_{i} \quad=\text { sampel }
\end{aligned}
$$

$$
R=X_{\text {imaks }}-X_{\text {imin }}
$$

Keterangan:

$R \quad=$ Range

$X_{i \text { maks }}=\mathrm{X}$ tertinggi

$X_{i \min }=\mathrm{X}$ terendah

Menentukan nilai $\overline{\bar{X}}$ dan $\bar{R}$

$$
\begin{aligned}
& \overline{\bar{X}}=\frac{\sum \bar{X}}{N} \\
& \bar{R}=\frac{\sum R}{N}
\end{aligned}
$$

$$
\begin{aligned}
& \text { Keterangan : } \\
& \overline{\bar{X}}=\text { rata-rata } \bar{X} \\
& \sum \bar{X}=\text { jumlah rata-rata } \\
& N=\text { jumlah sampel } \\
& \text { Keterangan: } \\
& \bar{R} \quad=\text { rata-rata } \mathrm{R} \\
& \sum R=\text { jumlah range } \\
& N \quad=\text { jumlah sampel }
\end{aligned}
$$

Hitung batas-batas kendali 3-sigma dari grafik kendali Xbar dan R.

Grafik kendali Xbar (batas-batas kendali 3-sigma):

UCL (Batas Pengendalian Atas) $=\bar{X}+A_{2} \bar{R}$

CL (Garis Pusat) $=\bar{X}$

LCL (Batas Pengendalian Bawah) $=X_{\text {double bar }}-A_{2} R_{\text {bar }}$

Keterangan:

$\begin{array}{ll}X_{\text {bar }} & =\text { rata-rata } \\ A_{2} & =\text { konstanta } \\ R_{\text {bar }} & =\text { rata-rata } \\ X_{\text {double bar }} & =\text { rata-rata } \\ \text { Grafik kendali } & \text { R } \text { (batas-bata } \\ \text { UCL } & =D_{4} R_{\text {bar }} \\ \text { CL } & =R_{\text {bar }} \\ \text { LCL } & =D_{3} R_{\text {bar }}\end{array}$

Keterangan: 


$$
\begin{array}{ll}
D_{4} & =\text { konstanta } \\
R_{\text {bar }} & =\text { rata-rata } \mathrm{R} \\
D_{3} & =\text { konstanta }
\end{array}
$$

Buat grafik kendali $X_{\text {bar }}$ dan $R_{\text {bar }}$

Gunakan grafik kendali dari $X_{b a r}$ dan $R_{b a r}$ untuk memantau proses yang sedang berlangsung dari waktu ke waktu, untuk seterusnya, dan segera ambil tindakan perbaikan apabila ada perubahan-perubahan yang tidak diinginkan pada proses itu. Analisis Kapabilitas Proses

Rasio Kapabilitas Proses/ process capability index/ nilai Cpk

$$
C p=\frac{U S L-L S L}{6 \sigma}
$$

Keterangan :

$$
\begin{array}{ll}
\mathrm{Cp} & =\text { Indeks Kapabilitas Proses } \\
\mathrm{USL} & =\text { Upper Spesification Limit/ Batas Spesifikasi Atas } \\
\mathrm{LSL} & =\text { Lower Spesification Limit/ Batas Spesifikasi Bawah } \\
\sigma & =\text { standar deviasi proses }
\end{array}
$$

Indeks Kapabilitas Proses/ process capability index atau nilai Cpk

$$
\text { Cpk }=\text { Minimum }\left[\frac{U S L-\mu}{3 \sigma}, \frac{\mu-L S L}{3 \sigma}\right]
$$

Keterangan

Cpk = Rasio Kapabilitas Proses

USL $\quad=$ Upper Spesification Limit/ Batas Spesifikasi Atas

LSL $\quad=$ Lower Spesification Limit/ Batas Spesifikasi Bawah

$\mu \quad=$ nilai rata-rata proses

$\sigma \quad=$ standar deviasi proses

Diagram Pareto

Diagram Sebab Akibat

\section{HASIL DAN PEMBAHASAN}

\section{Mengumpulkan Data Produksi dengan Check Sheet}

Mengumpulkan data pengamatan pada CV Jaya Abadi Sejahtera merupakan hal yang pertama

\begin{tabular}{|c|c|c|c|c|c|c|}
\hline \multirow{7}{*}{ 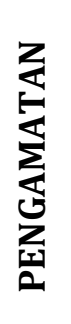 } & \multicolumn{6}{|c|}{ SAMPEL } \\
\hline & & 1 & 2 & 3 & 4 & 5 \\
\hline & $18 / 9 / 19$ & 0.92 & 0.92 & 0.93 & 0.92 & 0.92 \\
\hline & $19 / 9 / 19$ & 0.92 & 0.92 & 0.92 & 0.92 & 0.92 \\
\hline & $20 / 9 / 19$ & 0.92 & 0.92 & 0.92 & 0.92 & 0.93 \\
\hline & $21 / 9 / 19$ & 0.92 & 0.91 & 0.92 & 0.93 & 0.92 \\
\hline & $23 / 9 / 19$ & 0.92 & 0.93 & 0.92 & 0.91 & 0.92 \\
\hline
\end{tabular}
dilakukan. Check Sheet ini berfungsi untuk mengumpulkan data penelitian pada air minum dalam kemasan $220 \mathrm{ml}$ yang berpatokan pada kualitas yang telah ditentukan oleh SNI 3553:2015.

Pengambilan sampel dilakukan selama empat belas hari, sejak tanggal 18 September 2019 hingga 3 Oktober 2019. Dalam satu hari dilakukan 5 kali pengamatan pada tiap-tiap standaryang telah ditentukan. Dari check sheet diatas dapat diketahui bahwa tidak ada produk yang memiliki kualitas menyimpang dari standar yang telah ditentukan.

Tabel 3. Pengamatan Kekeruhan 


\begin{tabular}{llllll}
\hline $24 / 9 / 19$ & 0.91 & 0.93 & 0.92 & 0.92 & 0.93 \\
$25 / 9 / 19$ & 0.93 & 0.91 & 0.93 & 0.92 & 0.92 \\
$26 / 9 / 19$ & 0.92 & 0.93 & 0.93 & 0.91 & 0.92 \\
$27 / 9 / 19$ & 0.92 & 0.92 & 0.91 & 0.92 & 0.93 \\
$28 / 9 / 19$ & 0.91 & 0.93 & 0.92 & 0.91 & 0.93 \\
$30 / 9 / 19$ & 0.92 & 0.92 & 0.92 & 0.93 & 0.91 \\
$1 / 10 / 2019$ & 0.93 & 0.91 & 0.91 & 0.93 & 0.92 \\
$2 / 10 / 2019$ & 0.92 & 0.93 & 0.92 & 0.91 & 0.92 \\
$3 / 10 / 2019$ & 0.91 & 0.93 & 0.92 & 0.92 & 0.92 \\
\hline
\end{tabular}

Tabel 4. Pengamatan $\mathrm{pH}$

\begin{tabular}{|c|c|c|c|c|c|c|}
\hline \multirow{16}{*}{ } & \multicolumn{6}{|c|}{ SAMPEL } \\
\hline & & 1 & 2 & 3 & 4 & 5 \\
\hline & $18 / 9 / 19$ & 7.4 & 7.4 & 7.3 & 7.3 & 7.4 \\
\hline & $19 / 9 / 19$ & 7.3 & 7.4 & 7.3 & 7.3 & 7.3 \\
\hline & $20 / 9 / 19$ & 7.4 & 7.5 & 7.5 & 7.4 & 7.4 \\
\hline & $21 / 9 / 19$ & 7.5 & 7.5 & 7.5 & 7.4 & 7.3 \\
\hline & $23 / 9 / 19$ & 7.4 & 7.3 & 7.4 & 7.4 & 7.3 \\
\hline & $24 / 9 / 19$ & 7.3 & 7.4 & 7.3 & 7.4 & 7.4 \\
\hline & $25 / 9 / 19$ & 7.4 & 7.4 & 7.4 & 7.3 & 7.3 \\
\hline & $26 / 9 / 19$ & 7.3 & 7.3 & 7.4 & 7.3 & 7.3 \\
\hline & $27 / 9 / 19$ & 7.4 & 7.4 & 7.5 & 7.5 & 7.4 \\
\hline & $28 / 9 / 19$ & 7.3 & 7.5 & 7.5 & 7.4 & 7.3 \\
\hline & $30 / 9 / 19$ & 7.3 & 7.4 & 7.3 & 7.4 & 7.4 \\
\hline & $1 / 10 / 2019$ & 7.4 & 7.4 & 7.5 & 7.4 & 7.3 \\
\hline & $2 / 10 / 2019$ & 7.5 & 7.5 & 7.4 & 7.5 & 7.4 \\
\hline & $3 / 10 / 2019$ & 7.4 & 7.3 & 7.4 & 7.4 & 7.5 \\
\hline
\end{tabular}

Meski dalam tabel check sheet tidak ditemukan produk yang memiliki kualitas menyimpang, namun dalam jangka waktu 18 September 2019 hingga 3 Oktober 2019 masih ditemukan defect pada produk air minum dalam kemasan $220 \mathrm{ml}$ seperti yang tertera pada tabel 6 .

Tabel 5. Pengamatan Zat Terlarut

\begin{tabular}{|c|c|c|c|c|c|c|}
\hline \multirow{16}{*}{ 恣 } & \multicolumn{6}{|c|}{ SAMPEL } \\
\hline & & 1 & 2 & 3 & 4 & 5 \\
\hline & $18 / 9 / 19$ & 86 & 86 & 87 & 86 & 87 \\
\hline & $19 / 9 / 19$ & 86 & 87 & 86 & 86 & 87 \\
\hline & $20 / 9 / 19$ & 85 & 86 & 87 & 86 & 87 \\
\hline & $21 / 9 / 19$ & 86 & 87 & 86 & 86 & 87 \\
\hline & $23 / 9 / 19$ & 87 & 86 & 86 & 87 & 86 \\
\hline & $24 / 9 / 19$ & 87 & 86 & 87 & 86 & 86 \\
\hline & $25 / 9 / 19$ & 87 & 86 & 87 & 87 & 86 \\
\hline & $26 / 9 / 19$ & 86 & 86 & 87 & 86 & 86 \\
\hline & $27 / 9 / 19$ & 86 & 86 & 85 & 86 & 87 \\
\hline & $28 / 9 / 19$ & 85 & 87 & 86 & 85 & 86 \\
\hline & $30 / 9 / 19$ & 86 & 87 & 86 & 85 & 86 \\
\hline & $1 / 10 / 2019$ & 87 & 86 & 85 & 85 & 86 \\
\hline & $2 / 10 / 2019$ & 86 & 87 & 86 & 85 & 85 \\
\hline & $3 / 10 / 2019$ & 86 & 87 & 85 & 86 & 86 \\
\hline
\end{tabular}


Tabel 6. Data Produksi dan Defect Produk Air Minum

Kemasan 220 ml 18 September 2019 - 3 Oktober 2019

\begin{tabular}{|c|c|c|c|c|}
\hline \multirow[t]{2}{*}{ Tanggal } & \multirow[t]{2}{*}{ Produksi } & \multicolumn{3}{|c|}{ Defect } \\
\hline & & Kurang Isi & Terjatuh & Total \\
\hline $18 / 9 / 19$ & 293 & 32 & & 32 \\
\hline $19 / 9 / 19$ & 290 & 54 & 44 & 98 \\
\hline $20 / 9 / 19$ & 523 & 49 & 56 & 105 \\
\hline $21 / 9 / 19$ & 193 & 33 & 21 & 54 \\
\hline $23 / 9 / 19$ & 992 & & 50 & 50 \\
\hline $24 / 9 / 19$ & 245 & 15 & 35 & 50 \\
\hline $25 / 9 / 19$ & 196 & & 27 & 27 \\
\hline $26 / 9 / 19$ & 670 & & 17 & 17 \\
\hline $27 / 9 / 19$ & 339 & & 28 & 28 \\
\hline $28 / 9 / 19$ & 285 & 36 & 51 & 87 \\
\hline $30 / 9 / 19$ & 339 & 25 & 50 & 75 \\
\hline $1 / 10 / 2019$ & 448 & 13 & 74 & 87 \\
\hline $2 / 10 / 2019$ & 336 & 20 & 55 & 70 \\
\hline $3 / 10 / 2019$ & 228 & & 15 & 15 \\
\hline Total & 5377 & 272 & 523 & 795 \\
\hline
\end{tabular}

Dari tabel diatas dapat diketahui bahwa penyebab dari defect tersebut merupakan kemasan yang kurang isi, serta produk yang terjatuh.

\section{Membuat Histogram}

Data pada histogram menunjukkan sebanyak 272 buah defect yang disebabkan oleh kemasan yang kurang isi, dan 523 buah defect disebabkan oleh produk yang terjatuh ketika berada dalam ruang penyimpanan atau gudang.

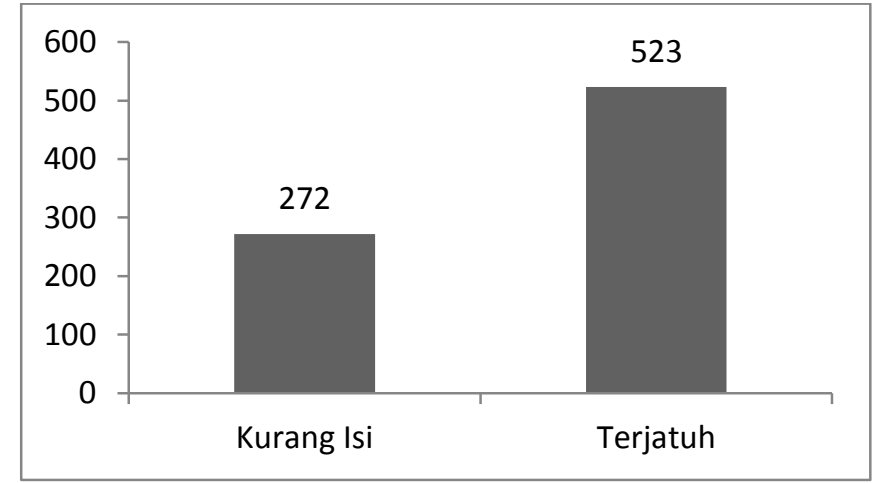

Gambar 1. Digram Histogram Defect Produk

\section{Membuat Grafik Kendali}

Grafik Kendali Kekeruhan

Menentukan nilai $\bar{X}$ dan $\mathrm{R}$ dari sampel standar kekeruhan

Untuk menentukan nilai $\bar{X}$ dan $\mathrm{R}$ dapat digunakan rumus sebagai berikut

$$
\begin{array}{ll}
\bar{X}=\frac{X i}{n i} & \mathrm{R}=\text { Xi maks }- \text { Xi min } \\
\text { Keterangan: } & \text { Keterangan: } \\
\overline{\mathrm{X}} \quad \text { rata-rata X } & R \quad=\text { Range } \\
& X_{\text {i maks }}=\text { X tertinggi }
\end{array}
$$




$$
\begin{aligned}
& \sum X_{i} \quad=\text { jumlah } \mathrm{X} \quad X_{i \min }=\mathrm{X} \text { terendah } \\
& n_{i} \quad=\text { sampel }
\end{aligned}
$$

\begin{tabular}{|c|c|c|c|c|c|c|c|c|c|c|}
\hline \multirow{16}{*}{ Z } & \multicolumn{6}{|c|}{ SAMPEL } & \multirow{2}{*}{$\begin{array}{c}\bar{X} \\
\left(\sum X i / n i\right)\end{array}$} & \multicolumn{3}{|c|}{ R (Xi maks - Xi min) } \\
\hline & & 1 & 2 & 3 & 4 & 5 & & X Maks & X Min & $\mathrm{R}$ \\
\hline & $18 / 9 / 19$ & 0.92 & 0.92 & 0.93 & 0.92 & 0.92 & 0.922 & 0.93 & 0.92 & 0.01 \\
\hline & $19 / 9 / 19$ & 0.92 & 0.92 & 0.92 & 0.92 & 0.92 & 0.92 & 0.92 & 0.92 & 0 \\
\hline & $20 / 9 / 19$ & 0.92 & 0.92 & 0.92 & 0.92 & 0.93 & 0.922 & 0.93 & 0.92 & 0.01 \\
\hline & $21 / 9 / 19$ & 0.92 & 0.91 & 0.92 & 0.93 & 0.92 & 0.92 & 0.93 & 0.91 & 0.02 \\
\hline & $23 / 9 / 19$ & 0.92 & 0.93 & 0.92 & 0.91 & 0.92 & 0.92 & 0.93 & 0.91 & 0.02 \\
\hline & $24 / 9 / 19$ & 0.91 & 0.92 & 0.92 & 0.92 & 0.93 & 0.92 & 0.93 & 0.91 & 0.02 \\
\hline & $25 / 9 / 19$ & 0.93 & 0.91 & 0.93 & 0.92 & 0.92 & 0.922 & 0.93 & 0.91 & 0.02 \\
\hline & $26 / 9 / 19$ & 0.92 & 0.93 & 0.93 & 0.91 & 0.92 & 0.922 & 0.93 & 0.91 & 0.02 \\
\hline & $27 / 9 / 19$ & 0.92 & 0.92 & 0.91 & 0.92 & 0.93 & 0.92 & 0.93 & 0.91 & 0.02 \\
\hline & $28 / 9 / 19$ & 0.91 & 0.93 & 0.92 & 0.91 & 0.93 & 0.92 & 0.93 & 0.91 & 0.02 \\
\hline & 30/9/19 & 0.92 & 0.92 & 0.92 & 0.93 & 0.91 & 0.92 & 0.93 & 0.91 & 0.02 \\
\hline & $1 / 10 / 2019$ & 0.93 & 0.91 & 0.91 & 0.93 & 0.92 & 0.92 & 0.93 & 0.91 & 0.02 \\
\hline & $2 / 10 / 2019$ & 0.92 & 0.93 & 0.92 & 0.91 & 0.92 & 0.92 & 0.93 & 0.91 & 0.02 \\
\hline & $3 / 10 / 2019$ & 0.91 & 0.93 & 0.92 & 0.92 & 0.92 & 0.92 & 0.93 & 0.91 & 0.02 \\
\hline & \multicolumn{6}{|c|}{ Total } & 12.888 & & & 0.24 \\
\hline
\end{tabular}

Tabel 7. Penghitungan $\overline{\boldsymbol{X}}$ dan R Kekeruhan

Menentukan nilai $\overline{\bar{X}}$ dan $\bar{R}$

$$
\begin{aligned}
\overline{\bar{X}} & =\frac{\sum \bar{X}}{N} \\
& =\frac{12.888}{14} \\
\bar{R} & =\frac{\sum R}{N} \\
\bar{R} & =\frac{0.24}{14} \\
& =0.017142857
\end{aligned}
$$

Keterangan :

$\overline{\bar{X}}=$ rata-rata $\bar{X}$

$\sum \bar{X}=$ jumlah rata-rata

$N=$ jumlah sampel

Keterangan:

$\bar{R} \quad=$ rata-rata $\mathrm{R}$

$\sum R=$ jumlah range

$N=$ jumlah sampel

Menentukan batas kendali 3-sigma

Grafik Kendali $\bar{X}$

$$
\begin{aligned}
\mathrm{UCL} & =\overline{\bar{X}}+\mathrm{A}_{2} \overline{\bar{R}} \\
& =0.9205714+(0.577 \times 0.017142857) \\
& =0.930462857 \\
\mathrm{CL} & =0.9205714 \\
\mathrm{LCL} & =\overline{\bar{X}}-\mathrm{A}_{2} \overline{\bar{R}} \\
& =0.9205714-(0.577 \times 0.017142857) \\
& =0.91068
\end{aligned}
$$

Grafik Kendali Rbar

$$
\begin{aligned}
\mathrm{UCL} & =\mathrm{D}_{4} \times \bar{R} \\
& =2.114 \times 0.017142857 \\
& =0.03625 \\
\mathrm{CL} & =0.017142857 \\
\mathrm{LCL} & =\mathrm{D}_{3} \times \bar{R} \\
& =0 \times 0.017142857 \\
& =0
\end{aligned}
$$

Keterangan:

$\bar{X} \quad=$ rata-rata $\mathrm{X}$

$A_{2}=$ konstanta

$\bar{R} \quad$ rata-rata $\mathrm{R}$

$\overline{\bar{X}} \quad=$ rata-rata $\bar{X}$

Keterangan:

$D_{4}=$ konstanta

$\bar{R}=$ rata-rata $\mathrm{R}$

$\mathrm{D}_{3}=$ konstanta 
Hasil analisis dengan alat pengendalian kualitas kontrol yaitu control chart terhadap tingkat kekeruhan produk air minum dalam kemasan 200ml pada CV Jaya Abadi Sejahtera pada 18 September 2019 - 3 Oktober 2019 denngan bantuan software Minitab 18 mengalami beberapa kali fluktuasi di beberapa hari, di antaranya pada $\bar{X}$ chart (CL $=0.9057$, UCL $=$ 0.93046 , LCL $=0.91068$ ) yang terjadi pada hari ke 1 hingga hari ke 3 (18 September 2019 20 September 2019), lalu pada hari ke 4 hingga hari ke 6 (21 September 2019 - 24 September 2019) tidak terjadi fluktuasi dan cenderung memiliki nilai yang berdekatan dengan nilai CL, lalu terjadi peningkatan pada hari ke 7 dan ke 8 (25 September 2019 - 26 September 2019), dan kembali mengaliami penurunan di hari ke 9 (28 September 2019), yang selanjutnya pada hari ke 9 hingga hari ke 14 (27 September 2019 - 3 Oktober 2019) memiliki nilai yang stagnan.

Selanjutnya pada R chart kekeruhan (CL $=0.01714$, UCL $=0.03625, \mathrm{LCL}=0$ ), sejak hari ke 1 (18 September 2019) hingga hari ke 2 (19 September 2019) mengalami penurunan yang mengakibatkan grafik pada hari ke 2 menempel pada nilai UCL, lalu mengalami peningkatan pada hari ke 3 (20 September 2019) dan hari ke 4 (21 September 2019), yang selanjutnya mengalami nilai yang stagnan sejak hari ke 4 hingga hari ke 14 (21 September 2019 - 3 Oktober 2019).

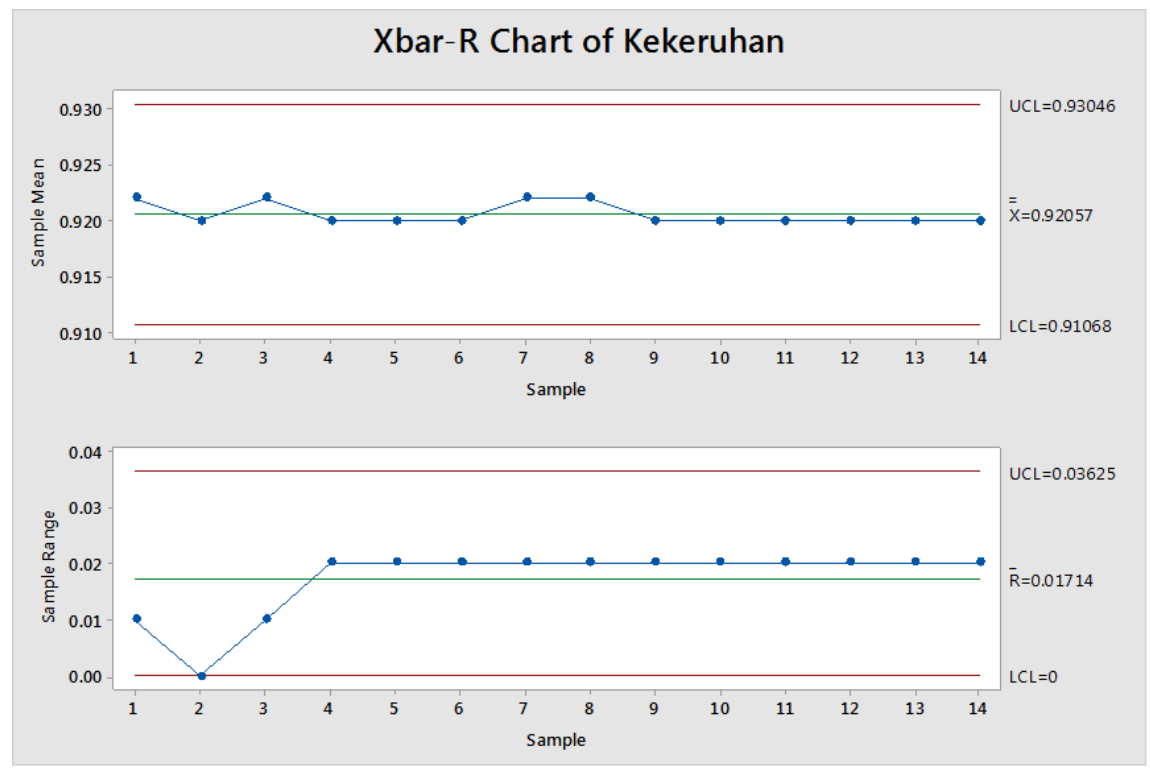

Gambar 2. Bagan Kendali $\bar{X}$ dan $\bar{R}$ Kekeruhan

Menurut Lindsay dan Evans (2007), jika nilai sampel jatuh di luar batas pengendalian atau jika pola yang tidak acak terjadi di dalam diagram, maka itu berarti bahwa penyebab khusus mempengaruhi proses tersebut dan dikatakan proses tidak stabil, sehingga perlu dilakukan perbaikan. Dari hasil penelitian diatas dapat disimpulkan bahwa terdapat penyebab khusus yang mempengaruhi proses tersebut dan dapat dikatakan proses tersebut dalam keadaan tidak stabil.

\section{Grafik Kendali pH}

Menentukan nilai $\bar{X}$ dan R dari sampel standar $\mathrm{pH}$

Untuk menentukan nilai $\mathrm{X}_{\mathrm{bar}}$ dan $\mathrm{R}$ dapat digunakan rumus sebagai berikut

$\begin{array}{ll}\bar{X}=\frac{X i}{n i} & \\ \text { Keterangan: } & \\ \bar{X} & =\text { rata-rata } X \\ \sum X_{i} & =\text { jumlah } X \\ n_{i} & =\text { sampel }\end{array}$

$\mathrm{R}=\mathrm{Xi}$ maks $-\mathrm{Xi}$ min

Keterangan:

$R \quad=$ Range

$X_{\text {imaks }}=\mathrm{X}$ tertinggi

$X_{i \min }=\mathrm{X}$ terendah

Tabel 8. Penghitungan $\bar{X}$ dan $\mathrm{R} p H$ 


\begin{tabular}{|c|c|c|c|c|c|c|c|c|c|c|}
\hline & \multicolumn{6}{|c|}{ SAMPEL } & \multirow{2}{*}{$\begin{array}{c}\bar{X} \\
\left(\sum X \mathbf{X}\right. \\
/ \mathbf{n i})\end{array}$} & \multicolumn{3}{|c|}{ R (Xi maks - Xi min) } \\
\hline & & 1 & 2 & 3 & 4 & 5 & & $\begin{array}{c}\text { X } \\
\text { Maks }\end{array}$ & $\mathrm{X}$ Min & $\mathrm{R}$ \\
\hline \multirow{15}{*}{ 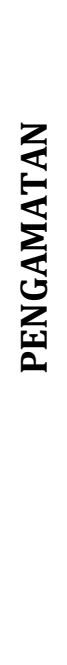 } & $18 / 9 / 19$ & 7.4 & 7.4 & 7.3 & 7.3 & 7.4 & 7.36 & 7.4 & 7.3 & 0.1 \\
\hline & $19 / 9 / 19$ & 7.3 & 7.4 & 7.3 & 7.3 & 7.3 & 7.32 & 7.4 & 7.3 & 0.1 \\
\hline & $20 / 9 / 19$ & 7.4 & 7.5 & 7.5 & 7.4 & 7.4 & 7.44 & 7.5 & 7.4 & 0.1 \\
\hline & $21 / 9 / 19$ & 7.5 & 7.5 & 7.5 & 7.4 & 7.3 & 7.44 & 7.5 & 7.3 & 0.2 \\
\hline & $23 / 9 / 19$ & 7.4 & 7.3 & 7.4 & 7.4 & 7.3 & 7.36 & 7.4 & 7.3 & 0.1 \\
\hline & $24 / 9 / 19$ & 7.3 & 7.4 & 7.3 & 7.4 & 7.4 & 7.36 & 7.4 & 7.3 & 0.1 \\
\hline & $25 / 9 / 19$ & 7.4 & 7.4 & 7.4 & 7.3 & 7.3 & 7.36 & 7.4 & 7.3 & 0.1 \\
\hline & $26 / 9 / 19$ & 7.3 & 7.3 & 7.4 & 7.3 & 7.3 & 7.32 & 7.4 & 7.3 & 0.1 \\
\hline & $27 / 9 / 19$ & 7.4 & 7.4 & 7.5 & 7.5 & 7.4 & 7.44 & 7.5 & 7.4 & 0.1 \\
\hline & $28 / 9 / 19$ & 7.3 & 7.5 & 7.5 & 7.4 & 7.3 & 7.4 & 7.5 & 7.3 & 0.2 \\
\hline & $30 / 9 / 19$ & 7.3 & 7.4 & 7.3 & 7.4 & 7.4 & 7.36 & 7.4 & 7.3 & 0.1 \\
\hline & $1 / 10 / 2019$ & 7.4 & 7.4 & 7.5 & 7.4 & 7.3 & 7.4 & 7.5 & 7.3 & 0.2 \\
\hline & $2 / 10 / 2019$ & 7.5 & 7.5 & 7.4 & 7.5 & 7.4 & 7.46 & 7.5 & 7.4 & 0.1 \\
\hline & $3 / 10 / 2019$ & 7.4 & 7.3 & 7.4 & 7.4 & 7.5 & 7.4 & 7.5 & 7.3 & 0.2 \\
\hline & \multicolumn{6}{|c|}{ Total } & 103.42 & & & 1.8 \\
\hline
\end{tabular}

1) Menentukan nilai $\overline{\bar{X}}$ dan $\bar{R}$

$$
\begin{array}{rlrl}
\bar{X} & =\frac{\sum \bar{X}}{N} & & \text { Keterangan : } \\
& =\frac{103.42}{14} & & \bar{X}=\text { rata-rata } \bar{X} \\
& =7.387142857 & & \sum \bar{X}=\text { jumlah rata-rata } \\
& & N=\text { jumlah sampel } \\
\bar{R} & =\frac{\sum R}{N} & & \\
& =\frac{1.8}{14} & & \text { Keterangan: } \\
& =0.128571 & & \sum R=\text { rata-rata } \mathrm{R} \\
& & N=\text { jumlah range } \\
\end{array}
$$

2) Menentukan batas kendali 3 sigma

a) Grafik Kendali $\bar{X}$

$$
\begin{aligned}
\mathrm{UCL} & =\overline{\bar{X}}+\mathrm{A}_{2} \bar{R} & & \text { Keterangan: } \\
& =7.387142857+(0.577 \times 0.128571) & & \bar{X}=\text { rata-rata } \mathrm{X} \\
& =7.461328571 & & A_{2}=\text { konstanta } \\
\mathrm{CL} & =7.387142857 & & \bar{R}=\text { rata-rata } \mathrm{R} \\
\mathrm{LCL} & =\overline{\bar{X}}-\mathrm{A}_{2} \bar{R} & & \overline{\bar{X}}=\text { rata-rata } \bar{X} \\
& =7.387142857-(0.577 \times 0.017142857) & & \\
& =7.312957 & &
\end{aligned}
$$

Keterangan:

$D_{4}=$ konstanta

$\bar{R}=$ rata-rata $\mathrm{R}$

$\mathrm{D}_{3}=$ konstanta

$\mathrm{CL}=0.128571$

$\mathrm{LCL}=\mathrm{D}_{3} \times \bar{R}$

$$
=0 \times 0.12857
$$

$=0$

Hasil analisis dengan alat pengendalian kualitas kontrol yaitu control chart terhadap tingkat pH produk air minum dalam kemasan $220 \mathrm{ml}$ pada CV Jaya Abadi Sejahtera pada 18 September 2019 - 3 Oktober 2019 dengan bantuan software Minitab 18 mengalami 
beberapa kali fluktuasi, di antaranya pada $\bar{X}$ chart pH (CL $=7.3871$, UCL $=7.4613$, LCL $=$ 7.3130) yang terjadi pada hari pertama (18 September 2019) hingga hari ke-3 (20 September 2019). Yang selanjutnya terjadi tingkatan nilai yang sama pada hari ke 3 (20 september 2019) hingga hari ke-4 (21 September 2019), namun pada hari ke-5 (23 September 2019) mengalami penuruna nilai yang selanjutnya nilai stagnan hingga hari ke-7 (25 september 2019), dan pada hari ke-8 (26 September 2019) nilai pH kembali mengalami penurunan, yang selanjutnya terus mengalami fluktuasi hingga hari ke-14 (3 Oktober 2019) dengan kondiri hari ke-13 (2 Oktober 2019) yang mengalami nilai $\mathrm{pH}$ yang menempel pada nilai UCL.

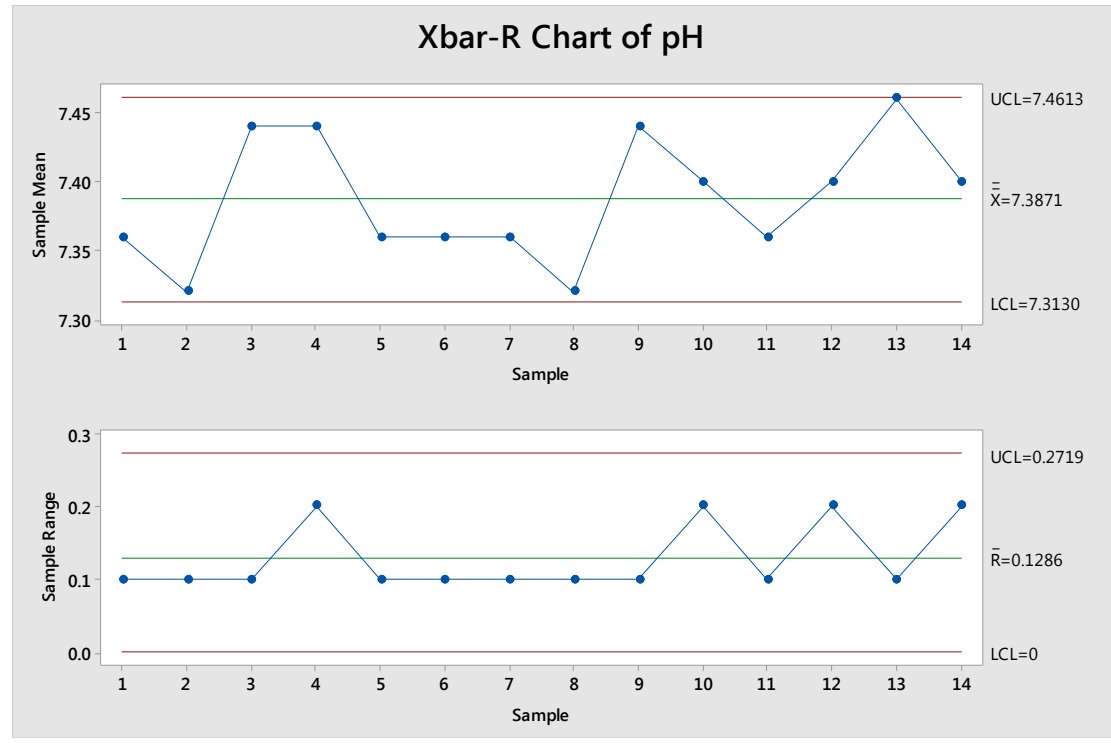

Gambar 3. Bagan Kendali Xbar Rbar pH

Selanjutnya pada R chart $\mathrm{pH}(\mathrm{CL}=0.1286, \mathrm{UCL}=0.2719, \mathrm{LCL}=0)$, pada hari pertama (18 September 2019) hingga hari ke-3 (20 September 2019) mengalami nilai yang cukup stagnan, dilanjut pada hari ke-4 (21 Septembr 2019) hingga hari ke-5 (23 September 2019) memiliki nilai yang cukup fluktuatif, dilanjut pada hari ke-5 (23 September 2019) hingga hari ke-9 (27 September 2019) mengalami nilai yang cukup stagnan,yang selanjutnya pada hari ke-10 (28 September 2019) hingga hari ke-14 (3 Oktober 2019) mengalami niai yang cukup fluktuatif.

Menurut Lindsay dan Evans (2007), jika nilai sampel jatuh di luar batas pengendalian atau jika pola yang tidak acak terjadi di dalam diagram, maka itu berarti bahwa penyebab khusus mempengaruhi proses tersebut dan dikatakan proses tidak stabil, sehingga perlu dilakukan perbaikan. Dari hasil penelitian diatas dapat disimpulkan bahwa terdapat penyebab khusus yang mempengaruhi proses tersebut dan dapat dikatakan proses tersebut dalam keadaan tidak stabil.

\section{Grafik Kendali Zat Terlarut}

3) Menentukan $\bar{X}$ dan $\mathrm{R}$ dari sampel standar Zat Terlarut Untuk menentukan nilai $X_{\mathrm{bar}}$ dan $\mathrm{R}$ dapat digunakan rumus sebagai berikut

$\begin{array}{ll}\bar{X}=\frac{X i}{n i} & \\ \text { Keterangan: } & \\ \overline{\mathrm{X}} & =\text { rata-rata } \mathrm{X} \\ \sum X_{i} \quad=\text { jumlah } \mathrm{X} \\ n_{i} \quad=\text { sampel }\end{array}$

$\mathrm{R}=$ Xi maks $-\mathrm{Xi}$ min Keterangan:

$\begin{array}{ll}R & =\text { Range } \\ X_{i \text { maks }} & =\text { X tertinggi } \\ X_{i \text { min }} & =\text { X terendah }\end{array}$


Tabel 11. Penghitungan $\bar{X}$ dan R Zat Terlarut

\begin{tabular}{|c|c|c|c|c|c|c|c|c|c|c|}
\hline & \multicolumn{6}{|c|}{ SAMPEL } & $\bar{X}$ & \multicolumn{3}{|c|}{ R (Xi maks - Xi min) } \\
\hline & & 1 & 2 & 3 & 4 & 5 & $\left(\sum X i / n i\right)$ & X Maks & X Min & $\mathrm{R}$ \\
\hline \multirow{15}{*}{ 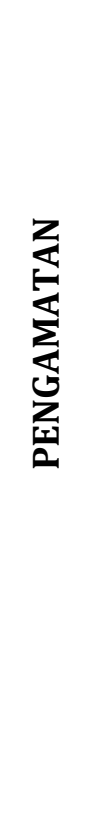 } & $18 / 9 / 19$ & 86 & 86 & 87 & 86 & 87 & 86.4 & 87 & 86 & 1 \\
\hline & $19 / 9 / 19$ & 86 & 87 & 86 & 86 & 87 & 86.4 & 87 & 86 & 1 \\
\hline & $20 / 9 / 19$ & 85 & 86 & 87 & 86 & 87 & 86.2 & 87 & 85 & 2 \\
\hline & $21 / 9 / 19$ & 86 & 87 & 86 & 86 & 87 & 86.4 & 87 & 86 & 1 \\
\hline & $23 / 9 / 19$ & 87 & 86 & 86 & 87 & 86 & 86.4 & 87 & 86 & 1 \\
\hline & $24 / 9 / 19$ & 87 & 86 & 87 & 86 & 86 & 86.4 & 87 & 86 & 1 \\
\hline & $25 / 9 / 19$ & 87 & 86 & 87 & 87 & 86 & 86.6 & 87 & 86 & 1 \\
\hline & $26 / 9 / 19$ & 86 & 86 & 87 & 86 & 86 & 86.2 & 87 & 86 & 1 \\
\hline & $27 / 9 / 19$ & 86 & 86 & 85 & 86 & 87 & 86 & 87 & 85 & 2 \\
\hline & $28 / 9 / 19$ & 85 & 87 & 86 & 85 & 86 & 85.8 & 87 & 85 & 2 \\
\hline & $30 / 9 / 19$ & 86 & 87 & 86 & 85 & 86 & 86 & 87 & 85 & 2 \\
\hline & $\begin{array}{l}1 / 10 / 201 \\
9\end{array}$ & 87 & 86 & 85 & 86 & 86 & 86 & 87 & 85 & 2 \\
\hline & $\begin{array}{l}2 / 10 / 201 \\
9\end{array}$ & 86 & 87 & 86 & 87 & 85 & 86.2 & 87 & 85 & 2 \\
\hline & $\begin{array}{l}3 / 10 / 201 \\
9\end{array}$ & 86 & 87 & 85 & 86 & 86 & 86 & 87 & 85 & 2 \\
\hline & & & & & & & 1207 & & & 21 \\
\hline
\end{tabular}

4) Menentukan nilai $\overline{\bar{X}}$ dan $\bar{R}$

$$
\begin{array}{rlrl}
\bar{X} & =\frac{\sum \bar{X}}{N} & & \text { Keterangan : } \\
& =\frac{1207}{14} & & \bar{X}=\text { rata-rata } X_{\text {bar }} \\
& =86.2148571 & & \sum \bar{X}=\text { jumlah rata-rata } \\
& & & \\
\bar{R} & =\frac{\sum R}{N} & & \text { Kumlah sampel } \\
& =\frac{21}{14} & & \bar{R}=\text { rata-rata } \mathrm{R} \\
& =1.5 & & \sum R=\text { jumlah range } \\
& & N=\text { jumlah sampel }
\end{array}
$$

5) Menentukan batas kendali 3-sigma

a) Grafik Kendali $\bar{X}$

$$
\begin{aligned}
\mathrm{UCL} & =\overline{\bar{X}}+\mathrm{A}_{2} \bar{R} \\
& =86.2148571+(0.577 \times 1.5) \\
& =87.07978571 \\
\mathrm{CL} & =86.2148571 \\
\mathrm{LCL} & =\overline{\bar{X}}-\mathrm{A}_{2} \bar{R} \\
& =86.2148571-(0 \times 1.5) \\
& =0
\end{aligned}
$$

Keterangan:

$\bar{X}=$ rata-rata $\mathrm{X}$

$A_{2}=$ konstanta

$\bar{R} \quad$ rata-rata $\mathrm{R}$

$\overline{\bar{X}} \quad$ rata-rata $\bar{X}$

b) Grafik Kendali $\bar{R}$

$$
\begin{aligned}
\mathrm{UCL} & =\mathrm{D}_{4} \times \bar{R} \\
& =2.114 \times 1.5 \\
& =3.172 \\
\mathrm{CL} & =1.5 \\
\mathrm{LCL} & =\mathrm{D}_{3} \times \bar{R} \\
& =0 \times 1.5 \\
& =0
\end{aligned}
$$

Keterangan:

$D_{4}=$ konstanta

$\bar{R}=$ rata-rata $\mathrm{R}$

$\mathrm{D}_{3}=$ konstanta 


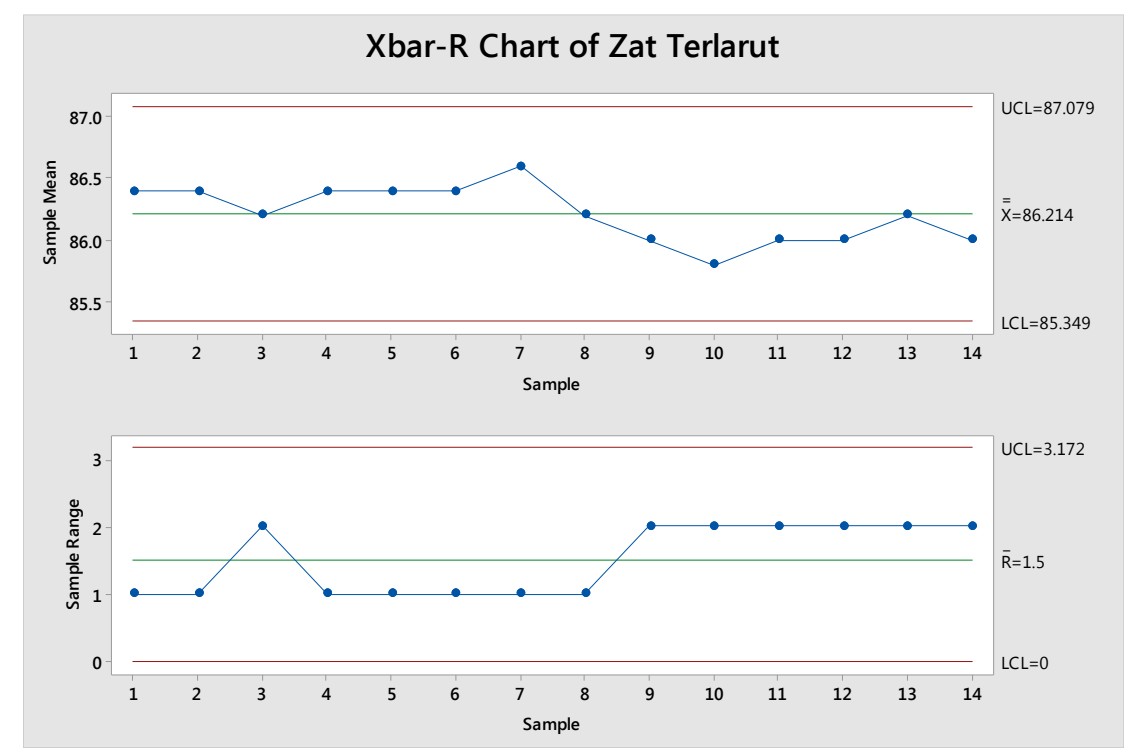

Gambar 4. Grafik Kendali $\bar{X}$ dan $\bar{R}$ Zat Terlarut

Hasil analisis dengan alat pengendalian kualitas kontrol yaitu control chart terhadap tingkat zat yang terlarut pada produk air minum dalam kemasan pada CV Jaya Abadi Sejahtera pada 18 September 2019 - 3 Oktober 2019 dengan bantuan software Minitab 18. Pada $\bar{X}$ chart zat yang terlarut (CL $=86.214, \mathrm{UCL}=87.079, \mathrm{LCL}=85.349)$ mengalami fluktuasi hampir disetiap hari. Namun pada hari ke-4 (21 September 2019) hingga hari ke-6 (24 September 2019) nilai pada tabel tersebut berada pada nilai yang stagnan.

Selanjutnya pada ${ }_{\mathrm{R}}$ chart zat yang terlarut $(C L=1.5$, UCL $=3.172, \mathrm{LCL}=0)$, pada hari pertama (18 September 2019) hingga hari ke-2 (19 September 2019) mengalami nilai yang stagnan. Yang selanjutnya mengalami fluktuasi pada hari k-3 dan ke-4, dilanjut pada hari ke-5 hingga ke-8 mengalami nilai yang cukup stagnan, lalu mengalami peningkatan pada hari ke-9, dilanjut mengalami nilai yang stagnan hingga hari ke-14.

Menurut Lindsay dan Evans (2007), jika nilai sampel jatuh di luar batas pengendalian atau jika pola yang tidak acak terjadi di dalam diagram, maka itu berarti bahwa penyebab khusus mempengaruhi proses tersebut dan dikatakan proses tidak stabil, sehingga perlu dilakukan perbaikan. Dari hasil penelitian diatas dapat disimpulkan bahwa terdapat penyebab khusus yang mempengaruhi proses tersebut dan dapat dikatakan proses tersebut dalam keadaan tidak stabil.

\section{Analisis Kapabilitas Proses}

Analisis Kapabilitas Proses Kekeruhan

1) Menentukan nilai $\sigma$

$$
\begin{aligned}
\sigma & =\frac{\bar{R}}{d_{2}} \\
& =\frac{0.017142857}{2.326} \\
& =0.0073
\end{aligned}
$$

2) Rasio Kapabilitas Proses/ process capability index/ nilai Cpk

$$
\begin{aligned}
C p & =\frac{U S L-L S L}{6 \sigma} \\
& =\frac{1.5-0.0}{6 \times 0.0073} \\
& =34.246
\end{aligned}
$$

Nilai Cp sebesar 34.246, nilai tersebut lebih dari 1 menunjukkan bahwa proses produksi dalam keadaan ideal. 
3) Indeks Kapabilitas Proses/ process capability index atau nilai Cpk

$$
\begin{aligned}
\text { Cpk } & =\text { Minimum }\left[\frac{U S L-\mu}{3 \sigma}, \frac{\mu-L S L}{3 \sigma}\right] \\
& =\text { Minimum }\left[\frac{1.5-0.9205714}{3 \times 0.0073}, \frac{0.9205714-0.0}{3 \times 0.0073}\right] \\
& =\text { Minimum }(26.45793,42.03522) \\
& =26.45793
\end{aligned}
$$

Nilai Cpk sebesar 26.45793, nilai tersebut lebih dari 1 menunjukkan bahwa proses produksi dalam keadaan ideal.

b. Analisis Kapabilitas Proses $\mathrm{pH}$

1) Menentukan nilai $\sigma$

$$
\begin{aligned}
\sigma & =\frac{\bar{R}}{d_{2}} \\
& =\frac{0.128571}{2.326} \\
& =0.055276
\end{aligned}
$$

2) Rasio Kapabilitas Proses/process capability index/ nilai Cpk

$$
\begin{aligned}
C p & =\frac{U S L-L S L}{6 \sigma} \\
& =\frac{8.5-6.0}{6 \times 0.055276} \\
& =7.537963
\end{aligned}
$$

Nilai Cp sebesar 7.537963, nilai tersebut lebih dari 1 menunjukkan bahwa proses produksi dalam keadaan ideal.

3) Indeks Kapabilitas Proses/ process capability index atau nilai Cpk

$$
\begin{aligned}
\text { Cpk } & =\text { Minimum }\left[\frac{U S L-\mu}{3 \sigma}, \frac{\mu-L S L}{3 \sigma}\right] \\
& =\text { Minimum }\left[\frac{8.5-7.387142857}{3 \times 0.055276}, \frac{7.387142857-6.0}{3 \times 0.055276}\right] \\
& =\text { Minimum }(6.710941,8.364985) \\
& =6.710941
\end{aligned}
$$

Nilai Cpk sebesar 6.710941, nilai tersebut lebih dari 1 menunjukkan bahwa proses produksi dalam keadaan ideal.

c. Analisis Kapabilitas Proses Zat Terlarut

1) Menentukan nilai $\sigma$

$$
\begin{aligned}
\sigma & =\frac{\bar{R}}{d_{2}} \\
& =\frac{1.5}{2.326} \\
& =0.644884
\end{aligned}
$$

2) Rasio Kapabilitas Proses/ process capability index/ nilai Cpk 


$$
\begin{aligned}
C p & =\frac{U S L-L S L}{6 \sigma} \\
& =\frac{500-0}{6 \times 0.644884} \\
& =129.2222
\end{aligned}
$$

Nilai Cp sebesar 129.2222, nilai tersebut lebih dari 1 menunjukkan bahwa proses produksi dalam keadaan ideal.

3) Indeks Kapabilitas Proses/ process capability index atau nilai Cpk

$$
\begin{aligned}
\text { Cpk } & =\text { Minimum }\left[\frac{U S L-\mu}{3 \sigma}, \frac{\mu-L S L}{3 \sigma}\right] \\
& =\text { Minimum }\left[\frac{500-86.21428571}{3 \times 0.644884}, \frac{86.21428571-0}{3 \times 0.644884}\right] \\
& =\text { Minimum }(213.8812,44.56321) \\
& =44.56321
\end{aligned}
$$

Nilai Cpk sebesar 44.56321, nilai tersebut lebih dari 1 menunjukkan bahwa proses produksi dalam keadaan ideal.

\section{Membuat Diagram Pareto}

Dari gambar 1 terlihat bahwa tingkat kerusakan disebabkan oleh dua faktor, diantaranta kemasan yang kurang isi dengan jumlah defect sebesar 277 buah, serta produk yang terjatuh di ruang penyimpanan dengan jumlah defect 523 buah. Dari dua faktor tersebut produk yang terjatuh menjadi faktor terbesar defect dari produk air dalam kemasan $220 \mathrm{ml}$. Untuk mengetahui sebab dari defect tersebut, selanjutnya akan dilakukan analisis sebab akibat pada defect tersebut.

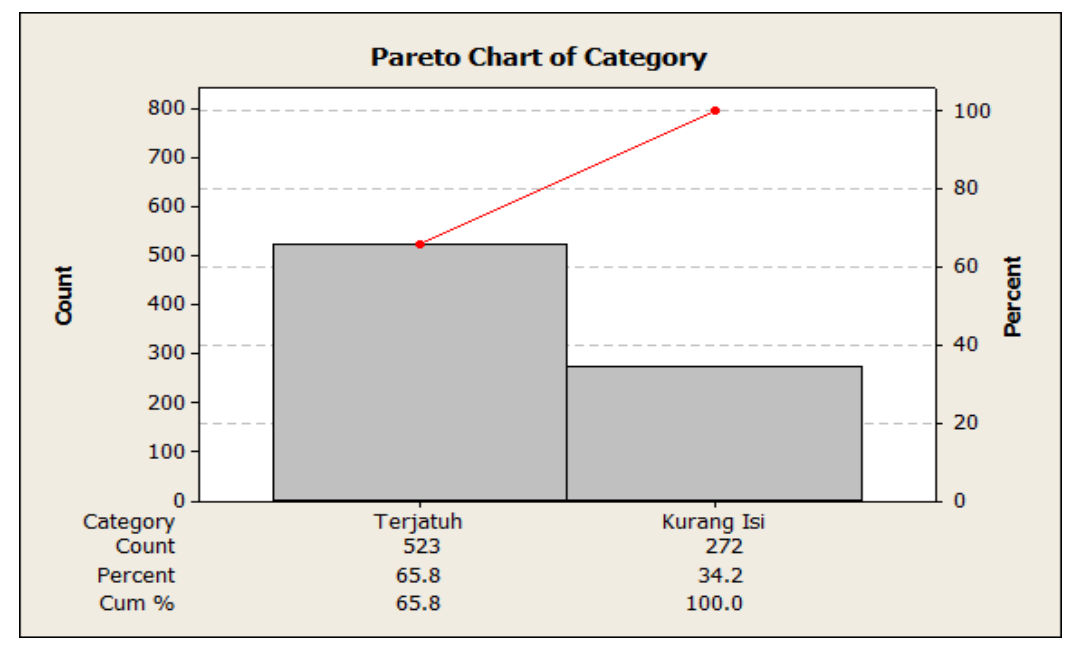

Gambar 5. Diagram Pareto

\section{Membuat Diagram Sebab Akibat}

Dari tabel 6 sudah diketahu bahwa terdapat defect yang bukan disebabkan oleh kualitas air yang buruk, melainkan dikarenakan oleh kemasan yang isi serta terjatuhnya produk ketika dalam ruang penyimpanan. Dari dua penyebab defect tersebut, ternyata penyebab utamanya adalah kelalaian dari manusia. Untuk sebab dari kemasan yang kurang isi diantaranya kurang telitinya pegawai dalam mengoperasikan mesin. Dan untuk produk yang terjatuh 
disebabkan ruang penyimpanan yang kurang aman serta pegawai yang terkadang ceroboh saat melakukan pengangkutan produk menuju ke bagian packing selanjutnya.

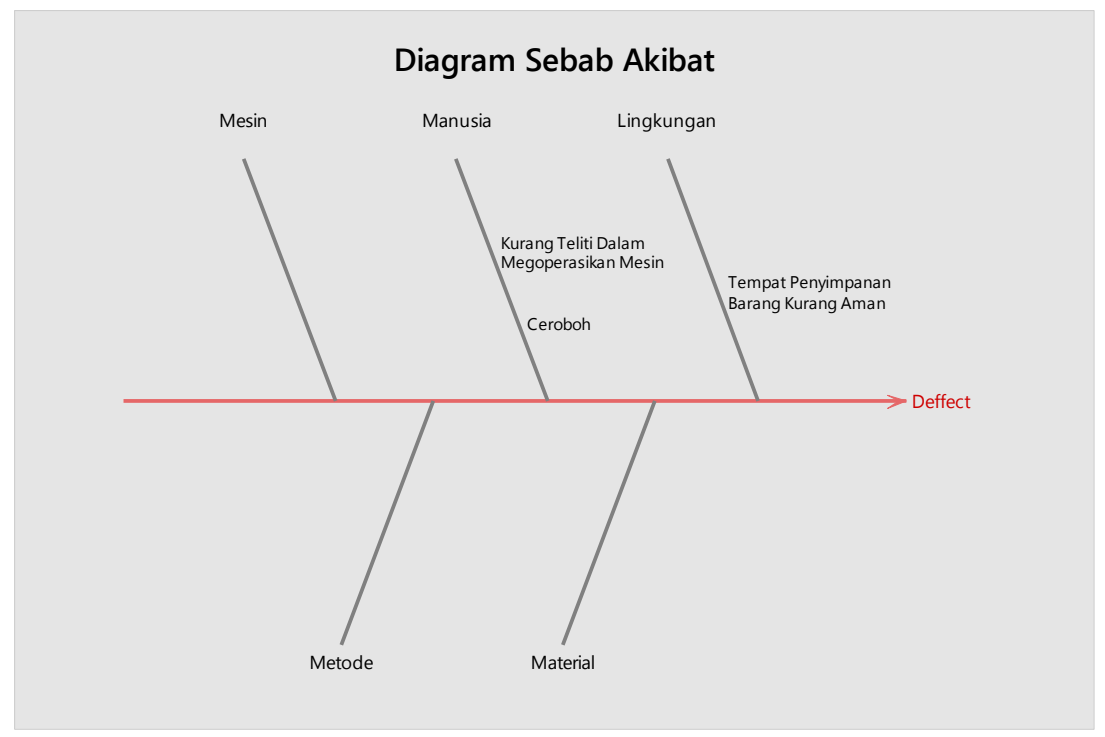

Gambar 6. Diagram Sebab Akibat

\section{Pembahasan}

Hasil pengumpulan data yang diolah kedalam check sheet selama 14 hari sejak 18 September 2019 hingga 3 Oktober 2019 akan dibahas lebih lanjut dalam pembahasan dibawah ini. Sampel yang digunakan dalam analisis ini sebanyak 14 subgrup, dengan setiap subgrup terdiri dari 5 sampel. Hasil produksi dalam 14 hari tersebut sebanyak 5377 buah dengan jumlah defect 795 buah. Dari defect tersebut ternyata bukan disebabkan oleh kualitas produk yang buruk, melainkan disebabkan oleh pengisian kemasan yang tidak sesuai dengan ketentuan serta produk yang terjatuh ketika dalam ruang penyimpanan. Penyebab dari defect tersebut diantara kelalaian dari pegawai CV Jaya Abadi Sejahtera yang mengoperasikan mesin pengisian kemasan air minum $220 \mathrm{ml}$, serta pegawai yang ceroboh saat memindahkan kemasan ke bagian packing selanjutnya yang menyebabkan produk air minum terjatuh. Selain itu lingkungan tempat penyimpanan yang kurang aman menyebabkan produk mudah terjatuh.

Selain defect tersebut penulis juga beberapa kali mendapati nilai pada Control Chart Kekeruan, pH, serta Zat yang Terlarut yang stagnan. Menurut Lindsay dan Evans (2007), jika nilai sampel jatuh di luar batas pengendalian atau jika pola yang tidak acak terjadi di dalam diagram, maka itu berarti bahwa penyebab khusus mempengaruhi proses tersebut dan dikatakan proses tidak stabil, sehingga perlu dilakukan perbaikan. Dari hasil penelitian diatas dapat disimpulkan bahwa terdapat penyebab khusus yang mempengaruhi proses tersebut dan dapat dikatakan proses tersebut dalam keadaan tidak stabil. Dari uraian menurut Lindsay dan Evans (2007) tersebut dapat dipastikan bahwa terdapat penyebab khusus yang mempengaruhi proses tersebut dan dapat dikatakan bahwa proses tidak stabil, maka dapat dikatakan bahwa kualitas dari produk tersebut tidak stabil.

Namun, pada penghitungan nilai Cp serta Cpk memiliki nilai lebih dari 1 ini menandakan bahwa proses produksi berjalan dalam keadaan ideal. Jika dibandingkan antara grafik kendali dengan nilai Cp dan Cpk yang berbanding terbalik, dapat dikatan bahwa harus dilakukan penelitian yang lebih lanjut terkait penyebab khusus yang terjadi pada proses produksi yang ditujukan oleh grafik kendali yang beberapa kali memiliki nilai yang stagnan, yang selanjutnya bisa dilakukan perbaikan pada penyebab khusus tersebut. 


\section{KESIMPULAN}

\section{Simpulan}

Berdasarkan analisis yang dilakukan pada CV Jaya Abadi Sejahtera mengenai pengendalian kualitas, dapat diperoleh kesimpulkan sebagai berikut: a) Proses produksi pada CV Jaya Abadi Sejahtera selama 14 hari sejak 18 September 2019 hingga 3 Oktober 2019 masih terdapat kecacatan dengan jumlah 795 buah, yang diantaranya 272 buah dikarekan kemasan yang kurang isi, dan 523 buah terjatuh di tempat penyimpanan, b) Nilai Grafik pada Control Chart Kekeruhan, $\mathrm{pH}$, serta Zat yang Terlarut beberapa kali mengalami nilai stagnan, yang artinya terdapat penyebab khusus yang mempengaruhi proses tersebut, sehingga proses tidak stabil, yang dapat dikatakan bahwa kualitas produk tersebut tidak stabil, c) Nilai Cp dan Cpk pada setiap standar produk memiliki nilai lebih dari 1, yang artinya proses produksi berjalan dengan baik. d) Pada diagram pareto ditemui bahwa penyebab utama dari defect produk air minum dalam kemasan $220 \mathrm{ml}$ adalah produk yang terjatuh diruang penyimpanan dengan julmah 523 buah dengan persentase $65.79 \%$, serta penyebab defect selanjutnya adalah kemasan yang kurang isi, dengan jumlah defect sebanyak 272 buah dengan persentase 34.21\%, e) Berdasarkan diagram sebab akibat dapat diketahui bahwa sebab dari defect produk air minum dalam kemasan $220 \mathrm{ml}$ adalah kelalaian pegawai saat mengoperasikan mesin, serta pegawai yang cenderung ceroboh saat memindahkan produk didalam ruang penyimpanan, selain itu kondisi ruang penyimpanan yang kurang aman juga menyebabkan produk mudah terjatuh.

\section{Implikasi}

Implikasi Manajerial

Dari hasil penelitian diatas maka yang dapat dilakukan oleh manajer operasional pada CV Jaya Abadi Sejahtera di antaranya: a) Melakukan perbaikan pada penyebab khusus yang terjadi pada saat proses produksi, b) Melakukan pelatihan kepada pegawai yang bertugas untuk mengoperasikan mesin pengisian kemasan, c) Memperbaiki ruang penyimpanan agar produk tidak mudah terjatuh.

Implikasi Teoritis: a) Penelitian selanjutnya diharapkan dapat meneliti hingga penyebab khusus yang terjadi pada proses produksi serta hingga tahap biaya kualitas, agar metode pengendalian kualitas ini lebih sempurna, b) Penelitian selanjutnya diharapkan dapat melakukan penelitian terhadap produk air minum dalam kemasan yang sudah beredar dipasaran, agar dapat diketahui apakah terdapat perubahan yang cukup siginifikan atau tidak pada saat produk sudah dipasarkan.

\section{DAFTAR PUSTAKA}

Ahmad Yani, S. \&. (2014). Analisa Pengendalian Kualitas Flat Flexible Cable (FFC) dengan menggunakkan Peta X dan R di PT Totoku Indonesia.

Andriani, D. P. (2017). Pengendalian Kualitas Kadar Air Produk Kerupuk Udang Berbasis SNI Menggunakan Statistical Quality Control Method .

Assauri, S. (2008). Manajemen Produksi dan Operasi. Jakarta: Fakultas Ekonomi Universitas Indonesia.

Darmawan, A. S. (2017). Analisis Pengendalian Kualitas Produk Gula Krembong PT Perkebunan Nusantara X Dengan metode Statistical Quality Control (SQC).

Davis, G. (2012). In T. Sunyoto, Dasar-Dasar Manajemen Pemasaran (p. 10). Yogyakarta: CAPS.

Elwood S. Buffa, Rakesh K. Sarin. (1996). Manajemen Operasi \& Produksi Modern. Jakarta: Binarupa Aksara.

Gasperz, V. (2005). Total Quality Management. Jakarta: Gramedia Pustaka Utama. 
Handoko, T. Hani. (2012). Dasar-Dasar Manajemen Produksi dan Operasi. Yogyakarta: BPFE-Yogyakarta.

Hatani. L. (2007). Manajemen Pengendalian Mutu Produksi Roti Melalui Pendekatan Statistical Quality Control (SQC).

Heizer, Rander. (2009). Manajemen Operasi. Jakarta: Salemba Empat.

Himawan, A. (2016). Pengendalian Kualitas Statistical Process Control Produk Genteng di UKM Soka Jepara.

Himawan, A. (2016). Pengendalian Kualitas Statistical Process Control Produk Genteng di UKM Super Soka Jepara.

Montgemory, D. C. (2001). Statistical Quality Control. Arizona: Arizona State University.

Nasution, N. M. (2005). Manajemen Mutu Terpadu: Total Quality Management. Bogor: Ghalia Indonesia.

Nastiti, H. (2013). Manajemen Pengendalian Mutu Produksi Roti Melalui Pendekatan Statistical Quality Control.

Nasution, M. N. (2010). Manajemen Mutu Terpadu. Jakarta: Ghalia Indonesia.

Pratama, Y. (2018). Kapabilitas Proses Mesin Pengemas Produk Pangan Bubuk Studi Kasus Pada Produk Pangan Terigu.

Prawirosentono. (2004). Manajemen Strategik \& Pengambilan Keputusan Korporasi. Jakarta: Bumi Aksara.

Rimantho, D. (2018). Kapabilitas Proses Untuk Pengendalian Kualitas Air Industri Farmasi.

Saiful Arifin, M. H. (2017). Analisis Pengendalian Mutu Produksi Melalui Pendekatan Statistical Quality Control Dalam Rangka Menjaga Kulitas Produk.

Siregar, A. (2010). Kualitas Pelayanan Penyuluh Pertanian Dan Kepuasan Petani. Jurnal Penyuluh Pertanian, 1-15.

Sunyoto, T. (2012). Dasar-Dasar Manajemen Pemasaran. Yogyakarta: CAPS.

Syamsul, M.M. dan Tanjung H. (2006). Manajemen Operasi. Jakarta: Grasindo.

Trijayanti, R. (2015). Analisis Kapabilitas Proes Dengan Pendekatan Bagan Kendali. 


